Dr Robert Cichórz, LL.M., West Pomeranian Business School, Szczecin

Dr doc. Yuriy Bilan

Kyiv National University of Technologies and Design

e-mail: rcichorz@zpsb.szczecin.pl

yuriy_bilan@yahoo.co.uk

\title{
CONSEQUENCES OF ADOPTING THE SCHENGEN ACQUIS FOR THE BORDER TRAFFIC BETWEEN POLAND AND UKRAINE
}

\begin{abstract}
The article aims at presenting the social and economic dimension of Schengen regulations, leaving aside its impact on cross-border co-operation. It outlines the legal framework of the Schengen acquis and its impact on Ukrainian-Polish relations in the examined fields. The tightening of these relations is important in view of Ukraine's aim to form a free trade area with the EU and to join the EU at some future point.
\end{abstract}

Key words: Schengen regulations, Ukrainian-Polish relations, cross-border co-operation 